\section{Evaluating the environmental sustainability strategies of the housekeeping department: the case of an international hotel chain in Hong Kong, China}

\author{
Monica Choy
}

Faculty of Management and Hospitality,

Technological and Higher Education Institute of Hong Kong - Chai Wan Campus, Hong Kong Island, Hong Kong, China, and

Justin Cheng and Karl Yu

Independent Investigator, HKSAR, Hong Kong, China
Housekeeping department

Received 9 January 2021 Revised 2 February 2021 Accepted 2 February 2021

\begin{abstract}
Purpose - The purpose of this paper is to use the case of an international luxury hotel chain in Hong Kong to illustrate general environmentally-friendly practices in housekeeping. Six in-depth interviews were conducted with the housekeeping department staff to evaluate the effectiveness of the Hotel's environmental sustainability practices by analysing their benefits and limitations. Results reveal that all informants acknowledged the environmental sustainability strategies adopted by the Hotel, which can benefit stakeholders. Despite multiple green practices in hotel housekeeping, several strategies may not be as significant as expected with misaligned expectations from the management and the actual practices may create excessive workload for frontline room attendants with a lack of policy enforcement and supportive policies. Therefore, hotels should keep a mutual communication between the management and frontline employees prior to conducting environmentally- and employee-friendly practices. Given the labour-intensive nature of the hotel industry, the housekeeping department should ensure employment equality policy is in place with adequate environmentally friendly support for employees.
\end{abstract}

Keywords Hong Kong, Hotel, Environmental sustainability strategies, Housekeeping department

Paper type Research paper

\section{Introduction}

The concept of "environmentally friendly" practices had appeared in several European countries and in the USA since 1980s (Wong et al., 1996). In 1993, the Green Hotel Association (GHA, 2005) introduced the importance of applying environmentally friendly practices to protect the environment. In the same year, the International Hotels Environment Initiative, now known as the International Tourism Partnership (ITP), was established to regulate and establish standards

(C) Monica Choy, Justin Cheng and Karl Yu. Published in Tourism Critiques: Practice and Theory. Published by Emerald Publishing Limited. This article is published under the Creative Commons Attribution (CC BY 4.0) licence. Anyone may reproduce, distribute, translate and create derivative works of this article (for both commercial and non-commercial purposes), subject to full attribution to the original publication and authors. The full terms of this licence may be seen at http:// creativecommons.org/licences/by/4.0/legalcode

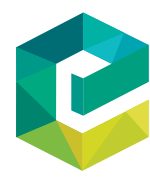

Tourism Critiques: Practice and Theory

Vol. 2 No. 1,2021 pp. $115-132$

pp. 115-132
Emerald Publishing Limited DOI 10.1108/TRC-01-2021-0001 
TRC

2,1

116

on hotel environmentally friendliness (International Tourism Partnership, 2014). The concept of sustainable development becomes further specific after the announcement of the United Nations Millennium Development Goals (MDGs), which outlines detailed action plans to achieve a sustainable future for all people. Sustainable development aims to achieve a balanced economic, social and environmental integration by addressing challenges related to poverty, inequality, climate change, environmental degradation, prosperity and peace and justice through the participation of multiple stakeholders from private sectors, government and civil society (UN, 2018). In this paper, we will see if the housekeeping practice can help keep a sustainable environment while frontline staff are willing and comfortable to keep up with this goal.

A unified definition of "green hotels" remains non-existent; however, this "green" concept is occasionally defined as hotels that are "environmentally responsible" and "environmentally friendly" (Kim and Han, 2010). Another definition states that "green hotels" should use "recycled", "low-polluting" or "energy-saving" materials (Chen and Chen, 2012). Apart from simply using "green" in hotels, the word "environmental sustainability" is also associated in compliance with corporate social responsibilities (CSR) and Sustainable Development Goals (SDGs) (Raub and Martin-Rios, 2019). Hotel CSR policy concentrates on education; skill enhancement; restoration; livelihood support; social problems; support to government policy, environmental protection and conservation; extended support and community development (Sudhagar and Samuel, 2019). SDGs are focussed on fostering economic growth and addressing various social needs, which include delivering decent employment, assuring sustainable production and consumption practices, achieving gender equality and protecting the environment (UN, 2018). The investigated hotel group claims it is following the SDGs for its staff. Studies have revealed that large hotel chain groups are more enthusiastic in adopting green policies than independent operators do, but the compliance level may vary (Jones and Comfort, 2019; Chen, 2019; Jarman-Walsh, 2018). People may have various descriptions and interpretations on the effort exerted by hotels, but all of them tend to share the same central idea that hotels should help alleviate environmental pressures during their operation (Casado, 2012).

The rapid expansion of advanced transportation has promoted tourism and hotel industry (Georgescu, 2016). The hotel sector represents a significant share of total tourism revenues of over US\$550bn in 2017 which was generated by a handful of international hotel chains, such as Marriot, Starwood, Hilton and Hyatt (Lock, 2019). Given the large consumption of water and electricity, the industry is exacerbating environmental damages by using natural reserves and generating a considerable amount of pollution (Sourvinou and Filimonau, 2018), which can pollute the environment (Mbasera et al., 2016). A report states that an average hotel releases an estimated 160-200 kg of carbon dioxide per square metre of room floor area per year, whereas the water consumption per guest per night is between 170 and 440 litres in a 5-star hotel (Bohdanowicz, 2005). On average, hotels produce $1 \mathrm{~kg}$ of waste per guest per night (International Tourism Partnership, 2014). Studies have consistently suggested the hotel industry should implement sustainable business practices (Jones et al., 2016). In the balance of keeping up with revenues and protecting the environment, hotels can make or break environment sustainability (Chen, 2019; Jarman-Walsh, 2018). On one hand, the hotel sector can generate profit and provide decent employment opportunities. On the other hand, they can contribute to building an environmentally-friendly society by reducing the impact of climate change and enhancing social capital (Pérez-Pineda et al., 2017). Some hotel chains have found ways to remain "green" by reducing energy consumption and waste production (Mak and Chang, 2019; Yoon et al., 2016). For instance, Hyatt has contributed to SGDs through different CSR initiatives. Waste management and recycling strategies are prepared to decrease hotel energy and water consumption and greenhouse gas emission, thereby 
enabling environmental stewardship culture (Hyatt, 2018). Marriott has pledged to become a sustainable hotel chain by minimising carbon and water usage and choosing environmentally responsible suppliers (Marriott International, 2017).

Notwithstanding the shared responsibilities of all stakeholders, business sectors have a critical role in contributing to environmental sustainability (Jones and Comfort, 2019). The hospitality industry was urged to adopt environmental sustainability strategies in their daily operations, which include setting priorities, developing and implementing green practices that are consistent with the developed SDGs and striving for balance among department economic growth, environment protection and social welfare improvement (Jones et al., 2016). However, a gap exists between the suggested global-level sustainable development blueprints (e.g. MDGs and SDGs) and the actual implementation at the organisational level because of the difference in sociocultural, economic, legal, workforce and customer demographics in each market (Raub and Martin-Rios, 2019). Consequently, individual hotels tend to adopt selected sustainability strategies, which advocate easy-to-implement green initiatives that satisfy the needs and expectations in the local context (Akenji and Bengtsson, 2014). Findings from extant studies have revealed implementation failure usually arising from companies who fail in identifying localisation issues and addressing vulnerable areas where require considerable support (Allen et al., 2019; Scott, 2018).

Hospitality is part of the tourism industry. Tourism is important to Hong Kong because it is one of the city's four pillar industries and contributes over $5 \%$ of the total local GDP. A total of 283 hotels can provide over 79,200 rooms in Hong Kong (Tourism Commission, 2018). In 2018, over 65 million of tourists visited Hong Kong; among them, 29 million were overnight visitors (HKTB, 2019). The hotel room occupancy rate was $91 \%$ in 2018 (Tourism Commission, 2019). The Environmental Protection Department (2015) reported that the pollution generated from hotels has become increasingly severe, with a total municipal waste of 3.71 million tonnes that was $3.9 \%$ more compared to that in 2014 . Therefore, hotels in the region should reduce pollution and waste for the sustainable prosperity of the hotel industry. Hong Kong's hotel industry has endeavoured to improve their environmental performance. For instance, this industry applies the Environmental Management System and participates in environmental certification programmes, such as Leadership like Energy and Environmental Design and ISO14001 (Environmental Protection Department, 2019; Chan, 2009; Chan and Ho, 2006). Green practices, which expectedly yields various benefits, such as energy saving and reducing waste, have become popular in hotel housekeeping (O'Neill, 2018). Despite the sustainable and responsible agenda within the hotel industry at the organisational level, it is expected that the effectiveness of green practices may not be high if it would hinder hotel operations (Linneberg et al., 2019). Similarly, the hotel housekeeping may encounter various challenges in promoting environmental sustainability strategies in daily operations. Numerous studies have examined the process of how hotel companies address environmental challenges (e.g. SDGs) based on hotels' corporate websites (Jones and Comfort, 2019; Jarman-Walsh, 2018). However, a scant number of studies have examined the thoughts of how the hotel employees, who play a pivotal role in executing green policies, realise the value of environmental sustainability. Identifying the relevant mindset of frontline staff can increase the effectiveness of implementing green hotel practices in the departmental and individual levels within a specific context (Raub and Martin-Rios, 2019). This study addresses the research gap to contribute to contemporary hotel operations. Therefore, this paper mainly aims to examine and investigate the effectiveness of the green practices applied in the housekeeping department in an international Hotel chain in Hong Kong, taking it as a reference for the Hong Kong hotel industry in a wide sense. Suggestions to improve the current green practices in hotel 
TRC

2,1

118

housekeeping are provided to optimise the environmental performance of ongoing sustainable development initiatives in the housekeeping department in the context of Hong Kong. This paper aims to answer the four specific questions listed.

Q1. What environmental sustainability strategies are adopted in the housekeeping department of the sample Hotel?

Q2. How do employees perceive the benefits of environmental sustainability strategies in housekeeping?

Q3. What are the barriers that can reduce the effectiveness of environmental sustainability strategies in housekeeping?

Q4. How beneficial are the housekeeping green practices in contributing to the Hotel's environmental sustainability strategies and the hotel industry in Hong Kong from the employees' perspective? How can the implementation of environmental sustainability strategies be improved?

\section{Literature review}

Sustainability refers to the mode of development that "meets the needs of the present without compromising the ability of future generations to meet their own needs" (WCED, 1987). The concept of sustainability concretises when the three elemental pillars (UN, 2005), namely, economic development, social development and environmental protection, can extend the planet's protection to include all countries, governments, private organisations and individuals (UN, 2018). Sustainability has been applied to numerous industries including hospitality (Mak and Chang, 2019). The United Nations Environment Program (UNEP) and World Tourism Organization (UNWTO) (2005) define sustainable tourism as the "tourism that takes full account of its current and future economic, social and environmental impacts, addressing the needs of visitors, the industry, the environment and host communities". One of the main objectives of sustainable tourism is to "make optimal use of environmental resources that constitute a key element in tourism development" (United Nations World Tourism Organization (UNWTO), 2005). As a key stakeholder in the tourism industry, hotels have adopted the same concept of sustainable tourism (Kim et al., 2012).

Hotels, as the major producer of commercial waste, are compelled to this environmental issue (Kasim et al., 2018). Green practices may be one of the most effective policies to increase the hotel's monetary and environmental status. Managers of environmentallyfriendly hotels are eager to "go green" to save energy and money (Singh, 2015). The US Green Building Council (2021) revealed that the hotel industry in the USA spends $\$ 4 \mathrm{bn}$ per year on energy. Reducing energy consumption by $10 \%$ can improve the average daily room rate for up to $\$ 1.35$ (Energystar, 2021). The hotel housekeeping department is responsible for keeping the property clean and comfortable while producing significant environmental risks and liabilities in their operation. Their crucial role in achieving sustainable development was often overlooked (O'Neill, 2018). Implementing sustainable practices in housekeeping can exhibit a notable impact on waste reduction. A study on hotels in Hong Kong revealed that up to $15 \%$ of energy and water can be conserved by implementing effective green practices in the housekeeping department (Deng and Burnett, 2002a, 2002b). Eaton Hong Kong, which is under Langham Hospitality Group, has successfully helped reduce waste production and won the green hotel prize awarded by Green Hotelier of 2015, Asia Pacific (Green Hotelier, 2015). Eaton has been the first hotel in Hong Kong to install their own water 
bottling system and introduce refillable amenities, which can save a total of 850,000 pieces of plastic waste each year (Eaton Hong Kong, 2015).

Apart from their environmental benefits, applying green programmes in hotel housekeeping can also provide economic benefits and employment opportunities. Despite absence of validated secondary data on the total number of employees working in the housekeeping department in Hong Kong, hospitality sector provides substantial employment opportunities (i.e. 38,800) for frontline employee in the first quarter of 2020 (Census and Statistics Department, 2020a). Green programmes may create more decent work for workers to make a living. As stated in the sample Hotel group's website, they offer their colleagues competitive wages, health care, retirement savings and performance-based incentives, while also offering industry-leading perks to eligible staff, including complimentary hotel stays, which should be considered "decent work" and "sustainable" as defined by the UN in their SDG framework. On the economic side, green programmes may help save natural as well as economic resources for our planet. For example, clean water accounts for $10 \%$ of the utility fee in numerous hotels, which was twice the amount of water that the hotel has consumed, because half of the total fee is paid for the disposal of waste water (Tuppen, 2013). Saving water as a housekeeping practice can decrease the amount of water used, thereby decreasing the price paid for disposing wastewater in the process. Reducing the frequency of a full-service room cleaning can decrease the money spent on detergents and electricity, while increasing the life of linens (Heney, 2009).

Apart from hotels in Hong Kong, hotels in other countries have also implemented green concepts; for example, the ITP is promoting the hotel industry can be a force for good and make a positive contribution to the UN's SDGs and to the Paris Climate Conference (COP21) (The International Tourism Partnership (ITP), 2017). A hotel in Hawaii has committed to protecting the environment by merely using botanical cleansers and disinfectants in housekeeping. Thus, switching from synthetic chemicals to natural detergents can reduce the occurrence of allergies, headaches and dry, chapped hands among housekeeping staff and simultaneously helps in protecting offshore coral reefs by preventing the intensification of water pollution (The Fairmont Orchid, 2004; Graci and Dodds, 2008). Studies have shown that green cleaners posed no harm to the environment because they do not contain or release harmful substances such as volatile organic compounds into the air when being used (Zabiegala, 2006). In addition, green cleansers lack irritants, abrasives and toxicity, whilst being highly biodegradable in the environment compared with synthetic cleaners (Fukey and Issac, 2014).

Guests' perception of health and safety exhibit a significantly positive influence on their purchase intention in green hotels (Jiang and Kim, 2015). Environmental protection has been promoted because customers recognise that business activities can cause serious damage to the environment (Han et al., 2018). Customers believe that they are a part of the "green programme" (Sánchez-Ollero et al., 2014) and feel a sense of satisfaction and strong "emotional benefits" for leaving a sustainable planet to the next generation (Kuminoff et al., 2010; Robinot and Giannelloni, 2010). The study revealed that customers can obtain "statusenhancing benefits" and tend to believe that they may leave a good impression to others by choosing green hotels (Jiang and Kim, 2015). Thus, acknowledging guests for their environmental efforts (Suki and Suki, 2015) and enhancing customers' sustainability mindset (Chen and Chen, 2012) are powerful forces for promoting sustainable hotel service provision and consumption.

Good intentions may not consistently be translated into desirable outcomes and occasionally become detrimental. Housekeeping staff expects a feasible and cost-effective green policy and practices but experiences extra burden such as sorting out rubbish to

Housekeeping department 
TRC

2,1

different recyclable items (Wan et al., 2017). In 2014, a group of 200 protesters in Toronto appealed to end the "Make A Green Choice" programme launched by an international hotel chain in 2009. The programme encouraged guests to forego housekeeping in exchange of a $\$ 5$ voucher or loyalty points in the interest of "conserving water, energy and other resources". The programme claimed to create environmental benefits, in which a one-night participation could save 49.2 gallons of water and sufficient natural gas to produce heat for a 400-square-foot room for $4 \mathrm{~h}$ (Sheraton Baltimore Washington Airport Hotel, 2017). However, this programme resulted in a burden amongst room attendants because the rooms that were not cleaned for several days required additional time and effort to tidy afterwards (Mojtehedzadeh, 2014). The malpractice amongst housekeepers can also harm the effectiveness of green strategies. A common practice that towels on the floor or in the bathtub should be laundered, whilst others left hanging should be kept for reuse (Heney, 2009). A hotel in New Orleans applied this towel reuse policy. However, the housekeeping staff changed all towels and linens daily even the guests participated in the environmental protection programme (Eilperin, 2010). This example has illustrated that environmental training and communication can influence the employees' ecological behaviour in compliance with the hotel's green policy (Chou, 2014; Sourvinou and Filimonau, 2018). The success of green practices was significantly related to employee participation and engagement (Kim and Choy, 2011). Green organisational climates, management support, employees' environmental knowledge, environmental awareness and environmental concern can influence the employees' willingness to adopt environmental management practices (Zientara and Zamojska, 2018; Chan et al., 2014). The lack of willingness to change long-established work routines and to monitor the actual purpose of the green initiatives can also diminish the room attendants' intention to execute sustainability practices (Iraldo et al., 2017).

Sustainable policy in a hotel is definitely related to gender equality and reduced inequalities in a society (The International Tourism Partnership (ITP), 2017). Females are considered to be easier affected by environmental and economic changes and, therefore, should be given an equal opportunity to develop their career with a decent work environment. Traditionally, housekeeping has been viewed as "household related" and females should be taking up more responsibilities (Thébaud et al., 2019). There are more women than men working in operation positions in the housekeeping department in Hong Kong (Employees Training Board,2016/ 2017) but only a minority of working females can be promoted to senior positions in the hotel industry (Segovia-Perez et al., 2019). Sustainable practices may buffer the negative effects of the deteriorating service quality (Van Rheede and Dekker, 2016). Several guests still express negative impressions of green hotel products and experiences (Robinot and Giannelloni, 2010). For instance, several green hotel initiatives such as refillable soap and shampoo dispensers, low-flow showerheads and linen reuse are considered as unfavourable amongst the guests because they perceive these practices as unsanitary, uncomfortable or an inconvenience during their stay. Results showed that although guests often appreciate hotels that contribute to protect the environment, they are generally unwilling to sacrifice their living standards and comfort levels (Baloglu and Jones, 2015).

\section{Methodology}

This paper aims to understand the Hotel's green policy in housekeeping and the employees' perception towards such policies in the context of an internationally branded hotel in Hong Kong. We collected information from the five-star international Hotel, which was claimed in 2014, the Hotel launched its 2020 Vision to tackle the most pressing global environmental issues they can influence. It is based around goals for reducing energy and water 
consumption and greenhouse gas (GHG) emissions at their hotels, recycling and waste reduction, supply chain sustainability and building efficiency. All of the challenges require collaboration with our industry, other businesses and thought leaders, according to the information provided in the Hotel chain website. This case study is appropriate for an empirical investigation that can provide qualitative and quantitative data to reflect a specific contemporary phenomenon within its real-life context (Yin, 2009). A purposive sampling method was used to gather the target participants. This method enables the researchers to select suitable respondents who can provide the desired information to answer the research questions and fulfil the research objectives (Saunders et al., 2009). Although purposive sampling is a nonprobability sampling design, this method is considered appropriate given that the selected respondents possess the knowledge and experience on the subject at hand. To ensure that diverse perspectives were represented in the study, six semi-structured interviews in Cantonese were conducted with the room attendants, supervisors and assistant managers, who worked for the research organisation from December 2017 to March 2018. Each interview lasted from 45 to $60 \mathrm{~min}$, and the questions focussed on:

- the current environmental sustainability strategies in housekeeping;

- employees' perception of the benefits and hurdles in executing green practices;

- benefits of housekeeping green practices in contribution to the Hotel's environmental sustainability strategies and the hotel industry in Hong Kong; and

- recommendations on the implementation of environmental sustainability strategies.

Using the participants' mother tongue in a qualitative interview is advantageous for obtaining rich responses by minimising language barriers and developing a good rapport (Welch and Piekkari, 2006). All interviews were recorded and transcribed after an informed consent was obtained. All respondents were told that their participation was completely voluntary and they could withdraw from the interview at any time. Moreover, the respondents were assured that the collected data would be kept strictly confidential and reported anonymously. Subsequently, a content analysis on the data obtained was conducted.

\section{Findings and discussion}

\subsection{Respondents' profile}

Six interviews with three room attendants, two supervisors and one assistant manager in the housekeeping department of a research organisation (referred to as "Hotel" in the subsequent mentions in this study) were conducted. The number of male and female respondents was evenly distributed. Their age ranged from 25 to 55 , and they have worked for the Hotel between one and six years on average. Most of them completed a secondary or postsecondary education, whereas only one received a tertiary education (Table 1).

Of the 25 workers in the housekeeping department, we had interviews with six, including three males and three females. However, given the general situation in Hong Kong, the majority (20 out of 25) working in the housekeeping department are women in their $40 \mathrm{~s}$ (Census and Statistics Department, 2020b). There may be various factors for women working in the housekeeping department. The level of salary can be one factor not attractive enough to young males to work for housekeeping (Baum et al., 2020). However, according to the website of the Hotel, it stated that gender is not a point of consideration in recruitment and the Hotel will only consider employees' work ability when considering their promotion. We did not specifically ask questions about gender difference in the interviews, but believed the imbalance of female to male ratio in the housekeeping department may be because of various social factors (Segovia-Perez et al., 2019; Nimri, et al., 2020). With the implementation
Housekeeping department 


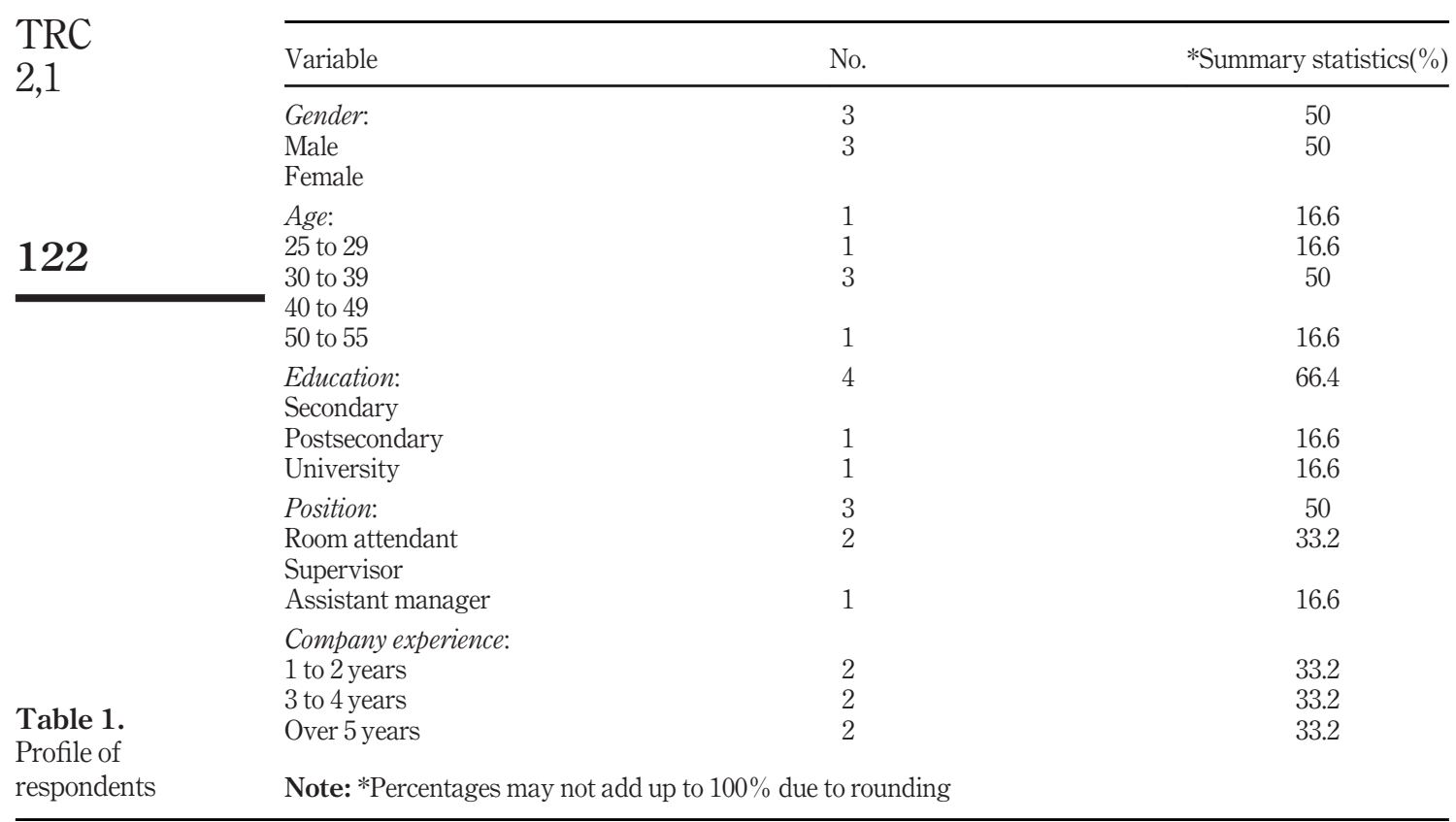

of SDGs strategies in hotels, it is believed that a more decent environment can be created for women to work.

\subsection{Environmental sustainability strategies in housekeeping}

4.2.1 Reusing and recycling. All interviewees cited "reuse and recycling" for their first answer in the interview given that the practice was simple and clear. The "three treasures" refer to "shampoo, conditioner and shower gel" bottles which are placed together in the bathroom. Informants were taught to collect reusable amenities in the guestroom and place them in the corresponding collection boxes for reuse if leftovers remain. The Hotel has collaborated with a distilled water brand to provide "light plastic bottles" that can be twisted easily to save space for recycling. The plastic bottles are collected by a recycling company daily. The assistant manager mentioned that a bed linen reuse programme was implemented, in which ripped or stained linen are turned into condemned cloth for cleaning. Ripped pillowcases are reused as excellent dusters for cleaning glasses and mirrors without scratching them. Consistent with previous studies, our findings showed that reusing and recycling material is a widely used practice for green hotels that implement CSR practices (Sudhagar and Samuel, 2019; Chen and Chen, 2012).

4.2.2 Integration of environmental considerations in daily operations. The Hotel integrates environmentally-friendly practices to their operational procedures. The assistant manager mentioned that under the bed linen reuse programme, the bed linen for guests is merely changed during the 1st, 4 th and 7 th day of their stay, unless the guests place a "Bed Linen Refresh Card" on the bedside to ask for a bed sheet replacement. To enhance energy efficiency, the electricity in the guestrooms can only be turned with a key card inserted into the card slot at the door. The light will be automatically off in five seconds if the key card is 
removed when guests leave the guestroom. A dual-flush toilet with "full flushing" and "half flushing" buttons is installed. Other environmentally-friendly practices include using a highpower destaining powder and energy-saving equipment. A highly soluble destain powder can dissolve naturally without heavy brushing and rinsing with plenty of water to remove the stain. Energy-saving vacuum machines were also adopted. The Hotel has exerted an effort to update their equipment for improved green practices and efficient use for the employees. These findings are consistent with previous studies, which indicate that hotel chains are prepared to implement practices that reduce energy consumption in their daily operations (Mak and Chang, 2019; Yoon et al., 2016; Casado, 2012).

\subsection{Benefits of environmentally-friendly strategies in housekeeping}

All informants have agreed that housekeeping green practices can contribute to the company's environmental management programme and generate various benefits for the environment, hotels, housekeeping staff and guests.

\subsubsection{Benefit for the environment}

4.3.1.1 Waste reduction and water and energy conservation. All room attendants have agreed that the "three treasures" can help reduce waste given that they typically clean about 20 rooms per day. The assistant manager stated that 600 rooms are available in the Hotel, with an average of $80 \%$ occupancy rate. Therefore, a total of 1,000 wasted empty bottles were produced daily. The staff members could realise the waste volume generated in the hotel industry, and they have agreed that the "reuse and recycle" practices can help reduce the number of waste, which is beneficial to the hotel industry and its stakeholders. Furthermore, green hotel practices can help reduce the water consumption, thereby benefitting the environment. The supervisor and assistant manager mentioned that water conservation strategies include the use of environmentally-friendly destain powders and the bed linen reuse programme, as well as the use of electronic key cards and dual flush toilets in guestrooms. Results confirm that environmental knowledge, awareness and concern are the key motivational sources for the employees' ecological behaviour (Zientara and Zamojska, 2018; Chan et al., 2014). From the implemented practices, we found the housekeeping green practices has strived and contributed to attainment of hotel's environmental sustainability strategies by reducing energy, water consumption and waste generation.

4.3.1.2 Benefits for hotels

4.3.1.2.1 Money saving. The assistant manager claimed that replacing bed linens less frequently can help save laundry fees given that this chore is one of the largest expenses in the housekeeping department. The laundry company charges the Hotel based on the weight of linen. By reducing the replacement of bed linens, the Hotel can save money, water and energy. The bed linen reuse programme can help reduce the money spent on laundry fees and extend the life cycle of bed linens. This view is consistent with Heney (2009), who claimed that green practices in housekeeping can provide economic benefit to the hotels. Similar to previous hotel-related studies (Wan et al., 2017), our findings also indicate that installing water-conserving fixtures, including the dual-flushing systems for toilets in guestrooms, is a common practice for green hotels, thereby decreasing water utility bills.

4.3.1.2.2 Increasing work efficiency. The assistant manager stated that an insufficient supply of amenities during peak season is evident, given that stocks of amenities merely arrive twice a week. Thus, unused and unopened amenities should be kept. In addition, the newly purchased vacuum machines exhibit better suction power than other types of vacuum machine, which helps save the time and effort in cleaning, increase room availability and create a decent work environment. With less effort to clean the carpet, females are beneficial for their less strong physical strength and the practice of using more
Housekeeping department

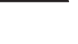


TRC

2,1

powerful vacuum machines thus creates greater gender equality and provides reduced inequalities. The results have demonstrated two things. Firstly, sustainability commitment and business performance are interrelated and interdependent (Jones and Comfort, 2019). Secondly, green practices may be one of the most effective policies to improve the monetary and environmental status of a hotel (Singh, 2015).

4.3.1.3 Benefits for employees. The provision of green cleaners and detergents was appreciated by all respondents because these cleaners are safer and less harmful to the environment compared with synthetic ones. These findings are consistent with the findings of Fukey and Issac (2014). Our findings indicate that room attendants approve the bed linen reuse programme because they must only "tidy up" the bed instead of adding another chore of changing the bed linens in every room, except for the guests who have requested for a replacement. Room attendants can save their effort and time in a room given that they must only focus on cleaning the bathroom, which create a more decent work environment with same economic returns. The use of destain powder and the bed linen reuse programme can significantly reduce the workload by decreasing physical work, which is consistent with Chan et al. (2014), who argued that employees are indispensable in implementing environmental programmes. Operational inconvenience and additional workloads can undermine the successful execution of hotel green practices (Linneberg et al., 2019).

4.3.1.4 Benefits for guests. During the interview, the assistant manager mentioned that several guests wrote a message which noted their appreciation of the environmental effort spent by the Hotel. Moreover, the guests were pleased to be part of this effort. For instance, they were given a sense of pleasure and satisfaction as they participate in green practices. This finding is similar to the finding of Sánchez-Ollero et al. (2014). However, the results contradicted a study in mainland China, which indicated that the green initiatives are insignificant for customer satisfaction (Lee et al., 2018). Our findings have contradicted previous studies, which indicated that hotel green practices induce a high risk of unpleasant customer experience (Robinot and Giannelloni, 2010). The findings indicated that the customer satisfaction level towards the hotel's green initiatives may vary in terms of sociocultural backgrounds and cultural values (Raub and Martin-Rios, 2019).

4.4 Barriers lowering the effectiveness of environmentally friendly strategies in housekeeping 4.4.1 Heavy workload amongst frontline room attendants. Owing to the high physical demand and heavy workload, room attendants are more prone to face stress and job burnout than other staff members (Chiang and Liu, 2017; Kensbock et al., 2017). Sorting the "threetreasures" and bringing them back to the collection point downstairs require extra effort especially in peak seasons with hundreds of rooms to clean every day. Room attendants must carry unused amenities around on a small trolley during their work hours. Manpower shortages and heavy workloads are the major barriers to implementing green management in the hotel industry (Wan et al., 2017).

4.4.2 Lack of enforcement. The supervisor and the assistant manager likewise claimed that closely monitoring the room attendants' job performance would be difficult. They stated that several room attendants would throw away toilet supplies. Thus, the "three treasures" practice is merely voluntary and recycling is considered as an "extra duty", particularly during peak seasons. The supervisory staff members are busy with inspecting the rooms for cleanliness and conducting administrative duties. Thus, they do conduct the first-hand execution of the green policy and cannot take close control whilst room attendants perform their duties, which make the policy "empty" in implementation to a certain extent. This result was supported by Iraldo et al. (2017), who suggested that an effective sustainability monitoring system is essential to improve the green practice implementation in hotels. 
4.4.3 Defective supportive policy. Room attendant A stated that the cleaning power of the destain powder was not as ideal as the management mentioned given that it takes about 20 min to soak. Room attendant $\mathrm{C}$ mentioned that only one bottle of destain powder is provided for each floor, whereas the management instructed to put it back immediately to the pantry after every single use to prevent the bottle from spilling and getting wet. Thus, no room attendant would waste plenty of time on travelling back and forth to get the destain powder. Although new vacuuming machines are available, several room attendants prefer to use the old vacuum machines without excessive suction power, particularly for the carpets in the guestrooms, which require extra strength and effort to be swept. The aforementioned examples have shown actual work environment may become the barriers to effectively implement environmental sustainability strategies. The supportive measures in the green practices are not as employee-friendly as expected, thereby significantly lowering the effectiveness of the green strategies used by the Hotel. Our results are consistent with previous studies, which claimed that resistance to change can reduce the employees' intention to implement green practices (Iraldo et al., 2017). This finding is consistent with the findings of extant studies, which indicated that support and commitment from the top management to provide the necessary tools and proper equipment are the key success factors of sustainability management effort (Mak and Chang, 2019).

\subsection{Usefulness of housekeeping green practices in contributing to industry's environmental sustainability strategies and recommendations for improvement}

All interviewees have agreed that the environmental strategies applied in housekeeping can help reduce the waste of the hotel industry in general. In addition, the respondents have suggested that improvements can be implemented in the following areas:

4.5.1 Improvement on supportive policy. Casado (2012) supported that the environmental sustainability philosophy must be integrated into the company's activities at all levels. For instance, room attendant B suggested that recycling boxes should be collected from the office daily by housemen, who support the housekeeping department staff. Two room attendants also hoped that the recycling boxes should be placed on every floor, instead of placing them in the office. They prioritised convenience for executing green practices, which can be correlated with their heavy workload and hasty working environment (Sarosi, 2017). Certain hotels have implemented the same green initiatives, in which recycle bins are placed on every floor landing for housekeepers to use (Brown Palace, 2019).

4.5.2 Enhancing communication. All supervisors have agreed that they should be obliged to establish a communication bridge between the management and the frontline employees. Thus, they should be proactive in reflecting the current operational issues, such as relaying the ruling opinion on the new vacuum machines to the department head to solve the problem and implement improvements. Moreover, supervisors should be further proactive in understanding the needs of room attendants, whilst enhancing the communication with the top management to help them set out employee-friendly decisions. Chou (2014) found that personal environmental norms exhibited a stronger effect on employees' green behaviour than other variables. Furthermore, the senior management should further emphasise green engagement to implement environmental policies, and the human resources management should provide environmental education among employees (Sudhagar and Samuel, 2019; Sourvinou and Filimonau, 2018).

4.5.3 Recruitment and understaffing. Before COVID-19 outbreak, existing hotels have been facing manpower constraints because of an overall decline of the young population's entrance into the workforce with the aging population, as mentioned during the Hotel Management Asia Summit (2018) that was held on 27 September 2018 in Hong Kong. A
Housekeeping department

$-1$


TRC

2,1

serious manpower shortage has occurred in numerous positions, including room attendant, room service butler and floor attendant positions (VTC, 2018). The pro-democracy movement and cumulated impact of the pandemic have caused career discontinuity and underemployment across all tourism-related industry sectors at all levels abruptly to release labour force to other industries (Yau, 2020). Hong Kong's double whammy of social unrest and the pandemic demonstrated precarious employment of tourism industry practitioners (Choy and Kamoche, 2020). The low income hospitality frontline, young and women workers are among one of the most vulnerable groups at risk of being made redundant or become a victim of underemployment partly because of their limited education and skill level (Baum et al., 2020) and perennial gender inequalities problem for women in the hospitality industry (Santero-Sanchez et al., 2015). While tourism and hospitality employees are struggling for alternative employment and some tourism organisations are trying to keep a tether to their manpower pool in wake of COVID-19, it is anticipated that there would be fierce competition for new bloods and those who opt for (or not) staying with their original sector/industry (Baum et al., 2020). Green practices have created "extra work" and used "additional time" without extra pay that affect employee decision to stay or leave with tourism-related organisations on one hand (Choy and Kamoche, 2020). This may not be a sustainable practice as the SDG framework aims to create a decent work environment and economic growth for the workers on the other hand (UN, 2015).

Supervisor B mentioned that understaffing is an evident issue in the Hotel. For instance, several staff members from the human resources department were called to help with housekeeping during peak seasons. This phenomenon could be the reason why some room attendants were uncooperative with environmental strategies. The supervisor believed that for the long-term benefits of the Hotel, housemen or "green assistants" are employed. Apart from creating more employment opportunities and economic values for all people, this is a better solution than raising the employees' salary given that the green programme should not be a responsibility of a specific position. Gender stereotypes remain prevalent in the hotel industry, in which millions of women work as room attendants and clean a total of 15.5 million hotel rooms worldwide (Sarosi, 2017). Therefore, the hotel industry should take steps to ensure a decent work environment for all, including women (UN, 2018).

4.5.4 Expand the scope of green practice. Supervisor A suggested that additional reuse strategies should be used. For example, laundry bags can be reused, particularly when a supply shortage exists. The toilet paper can be retained until the next guest stay provided that the thickness of paper should be greater than $3 \mathrm{~cm}$ to facilitate easy usage. The collected "three treasures" can be reused for removing the stench and slight stains of furniture or for use by employees in staff toilets and canteen. The assistant manager also suggested that amenities can be kept for the next stay if the plastic cover remains intact without being opened or getting wet.

4.5.5 Raising employees' environmental awareness. Studies reveal that environmental awareness can enhance the employee's intention to implement green practices (Chan et al., 2014) and the SDG framework. Supervisor A stated that the Hotel should raise the environmental awareness amongst employees before commanding them to adopt environmental practices. Thus, the employees must be daily reminded about environmental information during the morning briefing. Moreover, inviting staff to join outdoor green activities and letting them feel "green" and enjoy the nature, which is encouraged by the Hotel, is an impressive approach. Thus, the environmentally-friendly concept can be assimilated among themselves. O'Neill (2018) proposed the same idea that having eco-friendly products and processes are not sufficient if employees do not practice them. Each staff member's beliefs with regard to environmentally-friendly practices are the most 
significant. Hotels should offer training courses for their staff to conserve resources, which may be wasted otherwise (Sourvinou and Filimonau, 2018; Chou, 2014).

\section{Conclusion}

Multiple environmentally-friendly strategies are applied in the housekeeping department of the sample Hotel. Firstly, the reuse and recycle policy is implemented. Several housekeeping staff members recycle the toilet amenities and plastic water drinking bottles. Secondly, the Hotel develops its own linen reuse programme for the guests and the staff. Thirdly, green concepts including the SDG strategies proposed by UNs for the enhancement of hardware and equipment should be introduced in the housekeeping department. These practices include the use of electronic key cards, low-flush toilets, destain powders and new vacuum machines. Green practices have brought various benefits to the Hotel in particular and the hotel industry in general based on various perspectives. These practices can help protect the environment by reducing waste generation and water and energy consumption. Furthermore, they can reduce the expenses of the Hotel and increase the efficiency of cleaning rooms. From the employees' perspective, environmentally-friendly strategies can protect their health and significantly save their physical strength that was spent on cleaning. However, barriers that limits the effectiveness and thus reduces the benefits of green practices remain. For instance, the heavy workload of frontline employees is a reason why environmentally-friendly strategies cannot be successfully practiced. In addition, management issues, including the lack of enforcement and incomprehensible support policy, are also responsible for the ineffectiveness of the implementation of green practices.

All informants have agreed that housekeeping green practices contribute to the environmental sustainability strategies of sample Hotel as well as the hotel industry in Hong Kong at large. Multiple suggestions to address the limitations of green practices are provided by the frontline and the top management employees. Frontline employees believe that they would be further motivated if green practices provide convenience and rewards. Supervisors state that the management should start from the basics such as improving communication, creating decent jobs and raising the environmental awareness amongst employees. Green hotel initiatives should be operationally practical and sustainable to benefit the entire tourism industry. This study reveals the actual working environment in the housekeeping department of a hotel and the staff's perception towards environmental sustainability strategies. In this study, one of the most significant findings reported that a difference has consistently existed between expected outcomes and actual results. Communication and mutual understanding between the top management and the frontline employees are the foundations that yield efficient housekeeping practices in hotels. Environmental sustainability is a continuous journey that requires on-going improvement in micro and macro levels within the hotel industry. In this study, we focussed on reviewing the implementation barriers and actual practices in the housekeeping department of a hotel, without examining other departments in the hotel industry. Green practices should be adopted for the whole tourism industry but not just the hotels themselves. How the green practices can be promoted to the entire tourism is worth for further studies.

\section{References}

Akenji, L. and Bengtsson, M. (2014), "Making sustainable consumption and production the core of sustainable development goals", Sustainability, Vol. 6 No. 2, pp. 513-529.

Allen, C., Metternicht, G. and Wiedmann, T. (2019), "Prioritizing SDG targets: assessing baselines, gaps and interlinkages", Sustainability Science, Vol. 14 No. 2, pp. 421-438.

Baloglu, S. and Jones, T. (2015), "Energy efficiency initiatives at upscale and luxury US lodging properties: utilization, awareness, and concerns", Cornell Hospitality Quarterly, Vol. 56 No. 3, pp. 237-247.
Housekeeping department 
Baum, T., Mooney, S.K.K., Robinson, R.N.S. and Solnet, D. (2020), "COVID-19's impact on the hospitality workforce - new crisis or amplification of the norm?", International Journal of Contemporary Hospitality Management, Vol. 32 No. 9, pp. 2813-2829.

Bohdanowicz, P. (2005), "European hoteliers' environmental attitudes: greening the business", Cornell Hotel and Restaurant Administration Quarterly, Vol. 46 No. 2, pp. 188-204.

Brown Palace (2019), "Green initiatives”, available at: www.brownpalace.com/our-hotel/green-initiative/

Casado, M.A. (2012), Housekeeping Management, 2nd ed., John Wiley and Sons, New York, NY.

Census and Statistics Department (2020a), "Women and men in Hong Kong key statistics: table E003", available at: www.censtatd.gov.hk/hkstat/sub/sp200.jsp?productCode=D5250003

Census and Statistics Department (2020b), "Women and men in Hong Kong key statistics: table A4.10", available at: www.censtatd.gov.hk/hkstat/sub/sp180.jsp?productCode=B1130303

Chan, W. (2009), "Environmental measures for hotels' environmental management systems", International Journal of Contemporary Hospitality Management, Vol. 21 No. 5, pp. 542-560.

Chan, W. and Ho, K. (2006), "Hotels' environmental management systems (ISO 14001): creative financing strategy”, International Journal of Contemporary Hospitality Management, Vol. 18 No. 4, pp. 302-316.

Chan, E.S.W., Hon, A.H.Y., Chan, W. and Okumus, F. (2014), "What drives employees' intentions to implement green practices in hotels? The role of knowledge, awareness, concern and ecological behavior", International Journal of Hospitality Management, Vol. 40, pp. 20-28.

Chen, L. (2019), "Hotel chain affiliation as an environmental performance strategy for luxury hotels", International Journal of Hospitality Management, Vol. 77, pp. 1-6.

Chen, Y.C. and Chen, Y.T. (2012), "The advantages of green management for hotel competitiveness in Taiwan: in the viewpoint of senior hotel managers", Journal of Management and Sustainability, Vol. 2 No. 2, pp. 211-218.

Chiang, C.F. and Liu, B.Z. (2017), "Examining job stress and burnout of hotel room attendants: internal marketing and organizational commitment as moderators", Journal of Human Resources in Hospitality and Tourism, Vol. 16 No. 4, pp. 367-383.

Chou, C. (2014), "Hotels' environmental policies and employee personal environmental beliefs: interactions and outcomes", Tourism Management, Vol. 40, pp. 436-446.

Choy, M.W.C. and Kamoche, K. (2020), "Identifying stabilizing and destabilizing factors of job change: a qualitative study of employee retention in the Hong Kong travel agency industry", Current Issues in Tourism, doi: 10.1080/13683500.2020.1792853.

Deng, S.M. and Burnett, J. (2002a), "Energy use and management in hotels in Hong Kong”, International Journal of Hospitality Management, Vol. 21 No. 1, pp. 371-380.

Deng, S.M. and Burnett, J. (2002b), "Water use in hotels in Hong Kong", International Journal of Hospitality Management, Vol. 21 No. 1, pp. 57-66.

Eaton Hong Kong (2015), "Alchemy at Eaton, Hong Kong: turning green into gold”, available at: www. eco-business.com/press-releases/alchemy-at-eaton-hong-kong-turning-green-into-gold/

Eilperin, J. (2010), “Green’ hotels dilemma: conservation vs. service”, The Mercury News, available at: www.mercurynews.com/2010/04/14/green-hotels-dilemma-conservation-vs-service/

Employees Training Board (2016/2017), 2016-17 Annual Report, available at: www.erb.org/ authorsmith/documents/annual_report/2016-17/ERB-AR-2016-17.pdf

Energystar (2021), "Hotels: an overview of energy use and energy efficiency opportunities", available at: www.energystar.gov/sites/default/files/buildings/tools/SPP $\% 20$ Sales $\% 20$ Flyer $\% 20$ for $\%$ 20Hospitality $\% 20$ and $\% 20$ Hotels.pdf

Environmental Protection Department (2015), "Monitoring of solid waste in Hong Kong”, available at: www.wastereduction.gov.hk/sites/default/files/msw2015.pdf 
Environmental Protection Department (2019), “The directory of ISO14001 certified companies in Hong Kong”, available at: www.epd.gov.hk/epd/sites/default/files/epd/english/how_help/tools_ems/ files/2017_iso14k_eac_30.pdf

Fukey, L.N. and Issac, S.S. (2014), "Connect among green, sustainability and hotel industry: a prospective simulation study", International Journal of Social, Behavioral, Educational, Economic, Business and Industrial Engineering, Vol. 8 No. 1, pp. 296-312.

Georgescu, C. (2016), "The role of air transport in international tourism", Knowledge HorizonsEconomics, Vol. 8 No. 1, pp. 151-153.

Graci, S. and Dodds, R. (2008), "Why go green? The business case for environmental commitment in the Canadian hotel industry", Anatolia, Vol. 19 No. 2, pp. 251-270.

Green Hotel Association (2005), "Quick start to hotel conservation”, available at: www.greenhotels.com/ pressrel.php

Green Hotelier (2015), "Green hotelier awards 2015 winners announced”, available at: www. greenhotelier.org/our-news/industry-news/green-hotelier-awards-2015-winners-announced/

Han, H., Kim, W. and Lee, S. (2018), "Drivers of museum visitors' willingness to practice green activities", Social Behavior and Personality: An International Journal, Vol. 46 No. 2, pp. 233-247.

Heney, P.J. (2009), "When green works and when it doesn't', Hotel and Motel Management, Vol. 224 No. 13, p. 6.

Hong Kong Tourism Board (2019), "Monthly report: visitor arrival statistics - Dec 2018”, available at: https:// partnernet.hktb.com/filemanager/intranet/pm/VisitorArrivalStatistics/ViS_Stat_E/VisE_2018/Touri sm\%20Statistics\%2012\%202018_R1.pdf

Hotel Management Asia Summit (2018), available at: www.questexevent.com/HotelManagementSummit/ 2018/hongkong\#/about

Hyatt (2018), "Corporate responsibility at hyatt", available at: https://bit.ly/2TQwSf4

International Tourism Partnership (2014), "Environmental management for hotels", available at: www. greenhotelier.org/wp-content/uploads/2014/09/4-Waste-for-web-1-1.pdf

Iraldo, F., Testa, F., Lanzini, P. and Battaglia, M. (2017), "Greening competitiveness for hotels and restaurants", Journal of Small Business and Enterprise Development, Vol. 24 No. 3, pp. 607-628.

Jarman-Walsh, J. (2018), “2030 Sustainable development goals (SDG's) \& global hotel chain in leadership models in Japan”, Journal of Yasuda Women's University, Vol. 46, pp. 199-206.

Jiang, Y. and Kim, Y. (2015), "Developing multi-dimensional green value: extending social exchange theory to explore customers' purchase intention in green hotels: evidence from Korea", International Journal of Contemporary Hospitality Management, Vol. 27 No. 2, pp. 308-334.

Jones, P. and Comfort, D. (2019), "Sustainable development goals and the world's leading hotel groups", Athens Journal of Tourism, Vol. 6 No. 1, pp. 1-14.

Jones, P., Hillier, D. and Comfort, D. (2016), "Sustainability in the hospitality industry: some personal reflections on corporate challenges and research agendas", International Journal of Contemporary Hospitality Management, Vol. 28 No. 1, pp. 36-67.

Kasim, A., Dzakiria, H. and Bhat, I. (2018), "Sustainable water management in hotels: what leadership quality is required?", Indian Journal of Applied Hospitality and Tourism Research, Vol. 10, pp. 22-31.

Kensbock, S.L., Patiar, A. and Jennings, G. (2017), "Hotel room attendants' delivery of quality service", Tourism and Hospitality Research, Vol. 19 No. 3, pp. 382-393.

Kim, S. and Choy, Y. (2011), "Hotel employees' perception of green practices", International Journal of Hospitality and Tourism Administration, Vol. 14 No. 2, pp. 157-178.

Kim, Y. and Han, H. (2010), "Intention to pay conventional-hotel prices at a green hotel: a modification of the theory of planned behavior", Journal of Sustainable Tourism, Vol. 18 No. 8, pp. 997-1014.

Kim, Y., Palakurthi, R. and Hancer, M. (2012), "The environmentally friendly programs in hotels and customers' intention to stay: an online survey approach", International Journal of Hospitality and Tourism Administration, Vol. 13 No. 3, pp. 195-214.
Housekeeping
department

129 
TRC

2,1

Kuminoff, N.V., Zhang, C. and Rudi, J. (2010), "Are travelers willing to pay a premium to stay at a 'green' hotel? Evidence from an internal Meta-analysis of hedonic price premia", Agricultural and Resource Economics Review, Vol. 39 No. 3, pp. 468-484.

Lee, S., Sun, K., Wu, L. and Xiao, Q. (2018), "A moderating role of green practices on the relationship between service quality and customer satisfaction: Chinese hotel context", Journal of China Tourism Research, Vol. 14 No. 1, pp. 42-60.

Linneberg, M.S., Madsen, M.T. and Nielsen, J.A. (2019), "Micro-level translation of corporate sustainability: when strategy meets practice in the Danish hospitality sector", Journal of Cleaner Production, Vol. 240, pp. 118-159.

Lock, S. (2019), "Hotel industry: statistics and facts", available at: www.statista.com/topics/1102/hotels/

Mak, A.H.N. and Chang, R.C.Y. (2019), "The driving and restraining forces for environmental strategy adoption in the hotel industry: a force field analysis approach", Tourism Management, Vol. 73, pp. 48-60.

Marriott International (2017), "Marriott international unveils global sustainability and social impact commitments to deliver positive change", available at: https://bit.ly/2H90FOj

Mbasera, M., Du Plessis, E., Saayman, M. and Kruger, M. (2016), "Environmentally-friendly practices in hotels", Acta Commercii, Vol. 16 No. 1, pp. E1-E8.

Mojtehedzadeh, S. (2014), "Hotel workers protest Sheraton centre's 'green' program”, The Star, available at: www.thestar.com/news/gta/2014/12/04/hotel_workers_protest_sheraton_centres_green_program.html

Nimri, R., Kensbock, S., Bailey, J., Gayle, J. and Patiar, A. (2020), "Realizing dignity in housekepping work: evidence of five star hotels", Journal of Human Resources in Hospitality and Tourism, Vol. 19 No. 3, pp. 386-387.

O'Neill, S. (2018), “Talking point: why is it important for housekeeping to clean green?”, available at: www. greenhotelier.org/best-practice-sub/talking-point/talking-point-why-is-it-important-for-housekeepingto-clean-green/

Pérez-Pineda, F., Alcaraz, J.M. and Colón, C. (2017), "Creating sustainable value in the hospitality industry: a (critical) multi-stakeholder study in the Dominican Republic", Journal of Sustainable Tourism, Vol. 25 No. 11, pp. 1633-1649.

Raub, S. and Martin-Rios, C. (2019), "Think sustainable, act local: a stakeholder-filter-model for translating SDGs into sustainability initiatives with local impact", International Journal of Contemporary Hospitality Management, Vol. 31 No. 6, pp. 2428-2447.

Robinot, E. and Giannelloni, J.L. (2010), “Do hotels' 'green' attributes contribute to customer satisfaction?", Journal of Services Marketing, Vol. 24 No. 2, pp. 157-169.

Sánchez-Ollero, J., García-Pozo, A. and Marchante-Mera, A. (2014), "How does respect for the environment affect final prices in the hospitality sector? A hedonic pricing approach", Cornell Hospitality Quarterly, Vol. 55 No. 1, pp. 31-39.

Santero-Sanchez, R., Segovia-Pérez, M., Castro-Nuñez, B., Figueroa-Domecq, C. and Pilar TalónBallestero, P. (2015), "Gender differences in the hospitality industry: a job quality index", Tourism Management, Vol. 51, pp. 234-246, doi: 10.1016/j.tourman.2015.05.025.

Sarosi, D. (2017), "Tourism's dirty secret: the exploitation of hotel housekeepers", available at: www. oxfam.ca/publication/tourisms-dirty-secret-the-exploitation-of-hotel-housekeepers/

Saunders, M., Lewis, P., and Thornhill, A. (2009), Research Methods for Business Students, 5th ed., Pearson Education, Essex.

Scott, L. (2018), "SDG prioritization: is business on the right track?", available at: https://pwc.blogs.com/ sustainability/2018/01/sdg-prioritisation-is-business-on-the-right-track.html

Segovia-Perez, M., Figueroa-Domecq, C., Fuentes-Moraleda, F. and Munoz-Mazon, A. (2019), "Incorporating a gender approach in the hospitality industry: female executives' perceptions", International Journal of Hospitality Management, Vol. 76, pp. 184-193. 
Sheraton Baltimore Washington Airport Hotel (2017), "Make a green choice", available at: www. bwiairporthotel.com/make-a-green-choice.html

Singh, A. (2015), "Hotels housekeeping innovative trends and modern practices: an overview", Journal for Studies in Management and Planning, Vol. 1 No. 3, pp. 540-548.

Sourvinou, A. and Filimonau, V. (2018), "Planning for an environmental management programme in a luxury hotel and its perceived impact on staff: an exploratory case study", Journal of Sustainable Tourism, Vol. 26 No. 4, pp. 649-667.

Sudhagar, D.P. and Samuel, S. (2019), "Comparative analysis of corporate social responsibility policy (CSRP) from selected hotel brands and identifying areas for the CSRP enhancement", in Crowther, D. and Seifi, S. (Eds), The Components of Sustainable Development: Approaches to Global Sustainability, Markets, and Governance, Springer, Singapore, pp. 163-176.

Suki, N.M. and Suki, N.M. (2015), "Consumers' environmental behavior towards staying at a green hotel”, Management of Environmental Quality: An International Journal, Vol. 26 No. 1, pp. 103-117.

The Fairmont Orchid (2004), "Fairmont orchid goes chemical-free from room to reef", available at: http://pembertons.com/html/disinfectant/benefect/pdf/Fairmont_release.pdf

The International Tourism Partnership (ITP) (2017), "ITP goals for 2030 unite the hotel industry for a sustainable future", available at: www.tourismpartnership.org/global-goals/

Thébaud, S., Kornrich, S. and Ruppanner, L. (2019), "Good housekeeping, great expectations: gender and housework norms", Sociological Methods and Research, doi: 10.1177/0049124119852395.

Tourism Commission (2018), "Hong Kong: the facts - tourism”, available at: www.gov.hk/en/about/ abouthk/factsheets/docs/tourism.pdf

Tourism Commission (2019), "Tourism performance", available at: www.tourism.gov.hk/english/ statistics/statistics_perform.html

Tuppen, H. (2013), “Water management and responsibility in hotels”, available at: www.greenhotelier. org/know-how-guides/water-management-and-responsibility-in-hotels/

US Green Building Council (2021), "Leed and the hospitality industry", available at: www.usgbc.org/ drupal/legacy/usgbc/docs/Archive/General/Docs5301.pdf

United Nations Environment Program (UNEP) and World Tourism Organization (UNWTO) (2005), "Making tourism more sustainable: a guide for policy makers", available at: www.unep.fr/ shared/publications/pdf/DTIx0592xPA-TourismPolicyEN.pdf

United Nations World Tourism Organization (UNWTO) (2005), "Sustainable development of tourism", available at: $\mathrm{http}: / /$ sdt.unwto.org/content/about-us-5

United Nations (2005), “General assembly", available at: www.who.int/hiv/universalaccess2010/ worldsummit.pdf

United Nations (2015), "Millennium development goals and beyond 2015", available at: www.un.org/ millenniumgoals/pdf/Goal_7_fs.pdf

United Nations (2018), “About the sustainable development goals”, available at: https://bit.ly/2jHjQmD.

Van Rheede, A. and Dekker, D. (2016), "Hospitableness and sustainable development: new responsibilities and demands in the host-guest relationship", Research in Hospitality Management, Vol. 6 No. 1, pp. 77-81.

Vocational Training Council (2018), Manpower update report: hotel industry, available at: www.vtc. edu.hk/uploads/files/HITDC/Manpower $\% 20$ Update $\% 20$ Report $\% 20$ of $\% 20 H o t e l \% 20 I n d u s t r y \%$ $20 \mathrm{v} 18 \% 20$ (to $\% 20 \mathrm{web}) . p d f$

Wan, Y., Chan, S. and Huang, H. (2017), "Environmental awareness, initiatives and performance in the hotel industry of Macau”, Tourism Review, Vol. 72 No. 1, pp. 87-103.

Welch, C. and Piekkari, R. (2006), "Crossing language boundaries: qualitative interviewing in international business", Management International Review, Vol. 46 No. 4, pp. 417-437.

Housekeeping department

\section{$-2$}


TRC

2,1

Wong, V., Turner, W. and Stoneman, P. (1996), "Marketing strategies and market prospects for environmentally-friendly consumer products", British Journal of Management, Vol. 7 No. 3, pp. $263-281$.

World Commission on Environment and Development (1987), Towards sustainable development, Our common future: Report of the world commission on environment and development, available at: www.un-documents.net/ocf-02.htm

Yau, C. (2020), “Coronavirus: Hong Kong jobless rate climbs to $6.4 \%$, highest in nearly 16 years”, South China Morning Post, available at: www.scmp.com/news/hong-kong/hong-kong-economy/article/ 3106336/coronavirus-hong-kong-jobless-rate-climbs-64-cent

Yin, R. (2009), Case Study Research: Design and Methods, 4th ed., Sage, Thousand Oaks, CA.

Yoon, D., Jang, J. and Lee, J. (2016), "Environmental management strategy and organizational citizenship behaviors in the hotel industry", International Journal of Contemporary Hospitality Management, Vol. 28 No. 8, pp. 1577-1597.

Zabiegala, B. (2006), “Organic compounds in indoor environments”, Polish Journal of Environmental Studies, Vol. 15 No. 3, pp. 383-393.

Zientara, P. and Zamojska, A. (2018), "Green organizational climates and employee pro-environmental behaviour in the hotel industry", Journal of Sustainable Tourism, Vol. 26 No. 7, pp. 1142-1159.

\section{Further reading}

Alarcón, D.M. and Cole, S. (2018), "No sustainability for tourism without gender equality", Journal of Sustainable Tourism, Vol. 27 No. 7, pp. 903-919.

Paraskevas, A. and Brookes, M. (2018), "Human trafficking in hotels: an 'invisible' threat for a vulnerable industry", International Journal of Contemporary Hospitality Management, Vol. 30 No. 3, pp. 1996-2014.

\section{About the authors}

Dr Monica Choy is an Assistant Professor in the Faculty of Management and Hospitality at the Technological and Higher Education Institute of Hong Kong. Prior to embarking on her career in education, she acquired extensive business experience in the tourism and commercial sectors. She studied in China, Australia and Japan, and holds a BCom from the Curtin University of Technology, an MBA degree from the University of Sydney and University of New South Wales, an MSc in Hotel and Tourism Management from the Hong Kong Polytechnic University and a DBA from the University of Newcastle, Australia. Her research interests include tourism management and human resources management issues. She has published various articles in journals, such as current issues in tourism. Monica Choy is the corresponding author and can be contacted at: gehki.monica@gmail. com

Justin Cheng is a Former Instructor of the Division of Continuing Professional Education in Hong Kong Institute of Education (now The Hong Kong Education University). He has taught few courses on the use of English language. He also acted as an Editor for a number of books and journals in an international publishing house. Justin holds a master's degree in Communication and New Media from City University of Hong Kong and a bachelor's degree in Contemporary English Language from the Hong Kong Polytechnic University.

Karl Yu holds a bachelor's degree in Hotel Operations Management from the Technological and Higher Education Institute of Hong Kong, and is now an Industry Practitioner of an international hotel chain in Hong Kong.

For instructions on how to order reprints of this article, please visit our website:

www.emeraldgrouppublishing.com/licensing/reprints.htm

Or contact us for further details: permissions@emeraldinsight.com 